\title{
MULTIPLE LARGE PERIPHERAL GIANT CELL GRANULOMA: A CASE REPORT
}

\section{BÜYÜK BOYUTLARDA MULTIPL PERIFERAL DEV HÜCRELI GRANÜLOM: VAKA RAPORU}

\begin{abstract}
Mustafa Gümüşok ${ }^{1}$ Murat Özle ${ }^{2}$ Begüm Okur ${ }^{2}$ Anıl Seçkin ${ }^{2}$ Farid Museyibov ${ }^{3}$ Özlem Üçok ${ }^{1}$ Sedat Çetiner $^{2}$
\author{
${ }^{1}$ Gazi Üniversitesi Diş Hekimliği Fakültesi, \\ Ağız, Diş Ve Çene Radyolojisi Anabilim Dalı, \\ Ankara \\ ${ }^{2}$ Gazi Üniversitesi Diş Hekimliği Fakültesi, \\ Ağız, Diş Ve Çene Cerrahisi Anabilim Dalı, \\ Ankara \\ ${ }^{3}$ Gazi Üniversitesi Diş Hekimliği Fakültesi, \\ Oral Patoloji Anabilim Dalı, Ankara
}

\section{Yazıșma Adresi:}

Mustafa Gümüşok

Gazi Üniversitesi Diş Hekimliği Fakültesi Ağız

\section{ÖZET}

Periferal dev hücreli granülom (PDHG) oral bölgenin sık izlenen dev hücreli bir lezyonudur. PDHG'ler gerçek bir neoplazmı temsil etmezler. Etyolojileri çok açık olmayan bu lezyonların, travma veya lokal irritasyonlara bağlı gelişen reaktif bir lezyon olduğu düşünülmektedir. PDHG'lere kadınlarda erkeklere oranla daha sık, mandibulada ise maksilladan daha fazla rastlanılır. Gingiva veya dişsiz alveolar kret üzerinde kırmızı, kırmızı-mavi nodüler kitle şeklinde görülürler. Bu olgu raporunda, 48 yaşında erkek hastada görülen, maksilla sol santral kesici sağ kanin kesici dişler ve mandibula sağ santral kesici-sol kanin kesici dişler bölgesinde lokalize, yüzde asimetriye neden olan büyük boyutlu PDHG'ler sunulmuştur. Multipl PDHG vakasının radyolojik, klinik, histopatolojik bulguları ile birlikte teşhis, tedavi ve 6 aylık takibi rapor edilmiştir.
\end{abstract}

Diş Ve Çene Radyolojisi Asti Karşısı Emek

Ankara Ankara - Türkiye

E posta: mustafagumusok@hotmail.com

Kabul Tarihi: 25 Şubat 2015

\section{Balıkesir Sağlık Bilimleri Dergisi \\ ISSN: 2146-9601 \\ e-ISSN: 2147-2238}

bsbd@balikesir.edu.tr www.bau-sbdergisi.com

doi: $10.5505 /$ bsbd.2015.09709
Anahtar Kelimeler: Periferal dev hücreli granülom, mandibula, maksilla, multipl lezyon

\section{SUMMARY}

Peripheral giant cell granuloma (PGCG) is the most common oral giant cell lesion. PGCG presumably does not represent a true neoplasm. PGCG is believed to be stimulated by local irritation or trauma besides the causing of PGCG isn't known exactly. PGCG affects women more frequent than men and mandible more often than maksilla. It is usually seen as red or redhiss-blue, noduler mass on the gingiva or edentulous ridge. In the case report; multiple large PGCGs of 48 years old male patient causing facial asymmetry, localizated on the gingiva including the alveolar ridge of his maxillary left central incisor-right canin region and mandibular right central incisor-left canin region is presented. This case report contains radiological, clinical, histopathological findings, as well as diagnosis, treatment, follow-up of 6 months after totally excision of multiple PGCSs.

Key words: Peripheral giant cell granuloma, mandible, maxilla, multiple lesion

\section{INTRODUCTION}

Peripheral giant cell granuloma (PGCG) or the so-called "giant cell epulis" is a common giant cell lesion of the oral cavity. This lesion does not represent a true neoplasm. Although etiology is unknown, it is believed that it has reactive nature, stimulated by local irritation or trauma (1). PGDG clinically appears as a red, reddish-blue mass on the gingiva or on edentulous alveolar ridge. It may be sessile or pedunculated and ulcerated or non-ulcerated (2). This condition is called a peripheral giant cell tumor, giant cell epulis, osteoclastoma, reparative giant cell granuloma, or giant cell hyperplasia of the oral mucosa ${ }^{(3)}$.
The condition clinically resembles pyogenic granulomas. PGCG appears as a bluish-purplish lesion, compared to the bright red color of pyogenic granulomas ${ }^{(2)}$. In addition, these lesions are more likely to result in bone resorption, compared to pyogenic granulomas. The definitive diagnosis is established by biopsy ${ }^{(4)}$. 


\section{CASE}

A 48-years-old male patient presented with a rapidly growing swelling on the front side of the upper and lower jaw that persisted for the last two months, and severe halitosis. The patient's medical history was not remarkable for any systemic disorder. The extraoral examination revealed an asymmetric appearance in the lower lip of the patient (Figure 1).

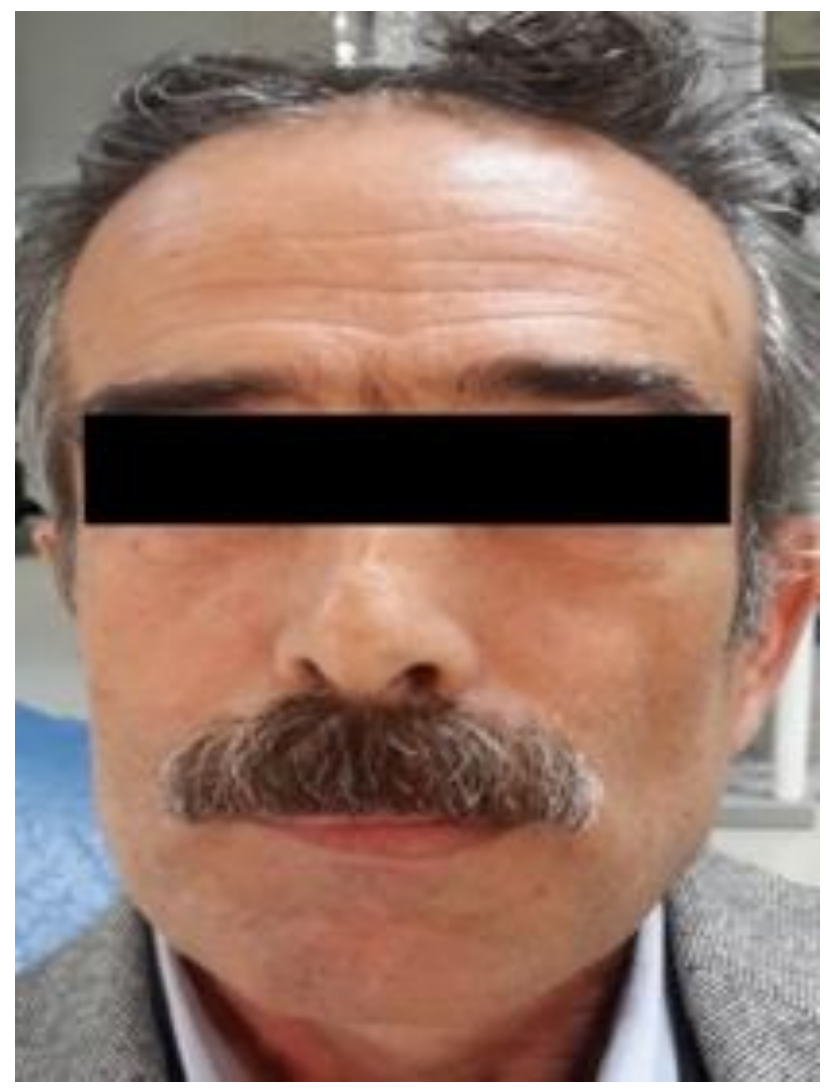

Figure 1: Extra-oral appearance of the asymmetry of the lower lip.

The intraoral examination of the patient revealed a firm mass lesion with a bright red appearance localized in the maxilla from the area of right canine to the area of the left lateral incisor. Another firm mass involving the teeth localized in the mandible from the area of the right central incisor to the area of the left premolar (Figure 2). The patient had an extensive build up of tartar and bacterial plaques. The teeth of patient was mobile due to loss of alveolar bone.

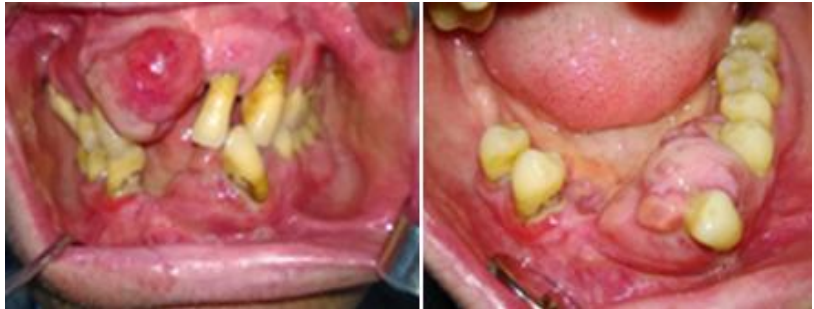

Figure 2: Peripheral giant cell lesions localized in the anterior regions of the maxilla and the mandible.

Panoramic radiograph revealed generalized extensive loss of the alveolar bone and enlargement of periodontal space (Figure 3).

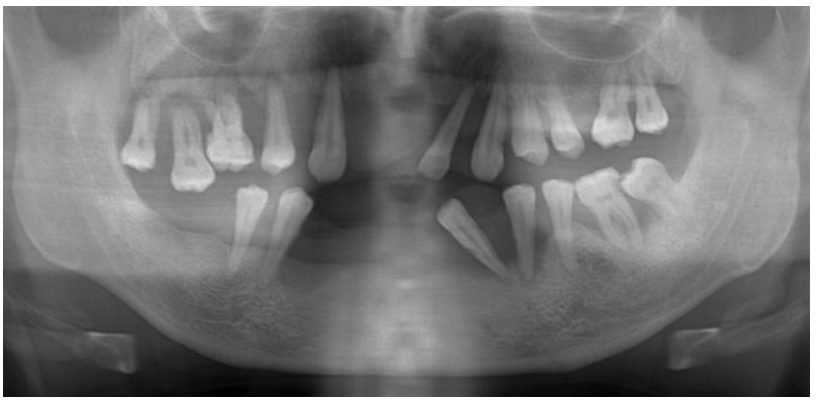

Figure 3: Generalized extensive loss of the alveolar bone and enlargement of periodontal space is observed in the panoramic radiograph of the patient.

The teeth associated with the lesion were extracted and the lesion was removed at the department of oral and maxillofacial surgery. An incisional biopsy was performed initially that did not reveal any findings of malignancy.Then, lesions were excised completely. (Figure 4).

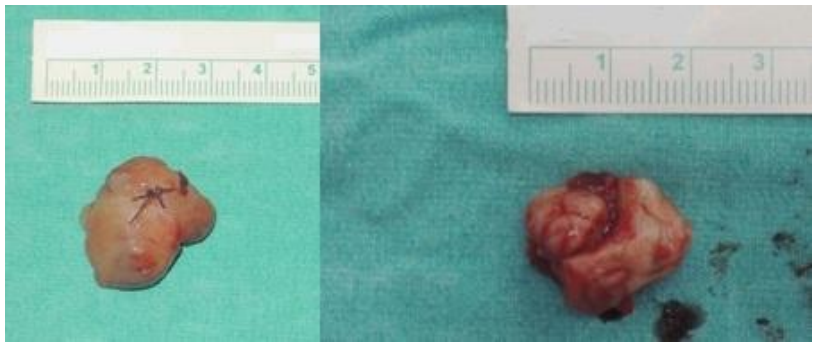

Figure 4: The appearance of the lesions after excision.

The relevant areas were curretaged. Hemostasis was achieved with compressive bandages after the excision. Complete hemostasis occurred after contouring the soft tissue using a diode laser. The diode laser was used (Lambda Scientifica srl, Doctor Smile Er \& Diode Laser) with a power setting of $810 \mathrm{~nm}$ of wavelength, $4.0 \mathrm{~W}$ of power, $0.5 \mathrm{~ms}$ continuous wave and $1000 \mathrm{~Hz}$ of frequency was selected. The wound margins were approximated with suturing and the operation was 
completed. The microscopic examination of the lesions (in the Department of Oral Pathology in Gazi University Faculty of Dentistry) revealed that lobulated reactive lesions underneath the epithelium of the oral mucosa. The connective tissue stroma was characterized by fibrohistiocytic infiltration and the accumulation of multiple multinucleated cells. These lesions were diagnosed as peripheral giant cell granulomas, based on the histopathological findings (Figure 5). The mobile teeth showing extensive alveolar resorption were extracted in a few sessions one week later. After recovery of the region, complete dentures were placed in the upper and lower jaws. There was no complications or recurrence after routine follow up of six months (Figure 6).

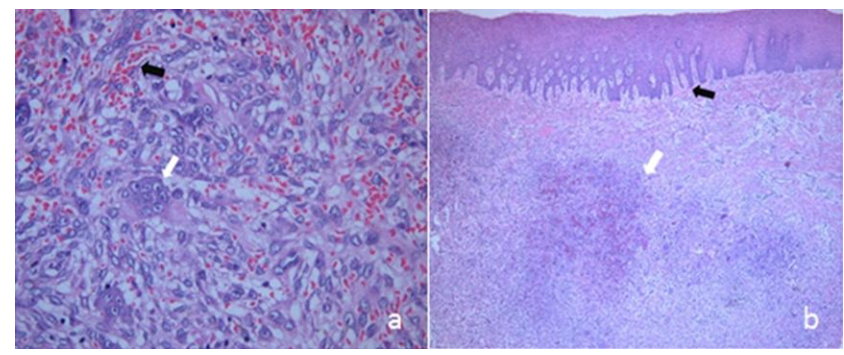

Figure 5: The histological examination of the lesion shows multinucleated giant cells (white arrow) and extravasated red blood cells $(H-E, A \times 400)(a)$, lobulated giant cells (white arrow),

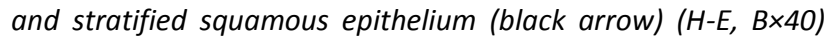
(b).

The patient was placed on a follow-up program.
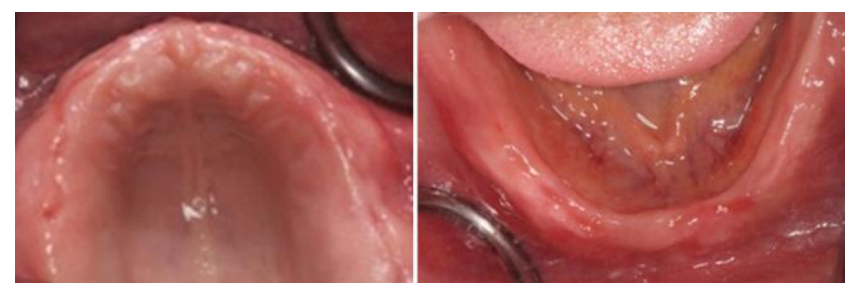

Figure 6: Intra-oral appearance after follow up of six month.

\section{DISCUSSION}

PGCGs are exophytic lesions occurring on the gingiva and alveolar ridge. These lesions often occur as a result of local irritations such as tartar, plaque, chronic infection, chronic irritation, tooth extraction, fillings with discordant margins, unstable dentures, and trapped food, and originate from the periodontal ligament or periodontium ${ }^{(5)}$. The lesions often measure less than 2 $\mathrm{cm}$ in size; however, they can also reach larger sizes ${ }^{(2)}$. The factors such as poor oral hygiene (tartar, gingival bleeding, and deep pockets) and xerostomia have been reported to play a role in the growth of these lesions ${ }^{(6)}$.
In the present case, the lesion was removed from the maxilla measured $4 \times 2.5 \times 2.5 \mathrm{~cm}$ and from the mandible measured $2.5 \times 2 \times 1.8 \mathrm{~cm}$. Poor oral hygiene is assumed to have contributed to the development of the large lesions in the patient.

Although PGCGs can occur at all ages, they are more commonly encountered in the fourth and sixth decades $(7,8)$. The lesion involves the maxilla more commonly than mandible, and females are more often affected than males ${ }^{(9)}$. PGCGs are soft tissue lesions, but they can cause erosion by affecting the underlying bone tissue $(10,11)$. Pain is not a significant problem in such lesions. In connection with persisting trauma, the lesion continues to grow $^{(4)}$.

The giant cell granulomas can rarely develop secondary to hyperparathyroidism ${ }^{(12,13)}$. The lesions caused by hyperparathyroidism are typically observed at the center of the bone, and these lesions are referred to as brown tumors ${ }^{(12)}$. The lesions localized inside the bone tissue in the lower jaw perforate cortical layer of the bone and spread to soft tissues, mimicking a peripheral lesion ${ }^{(12)}$. In the present case, panoramic radiographs did not reveal any intraosseous lesions.

These lesions are characterized by nodular multinucleated giant cells surrounded by fusiform and oval mesenchymal cells. These giant cells can contain few nuclei, but can also contain up to several dozens of nuclei. Some giant cells contain large, vesicular nuclei, while others contain small, pyknotic nuclei. Hemorrhagic fluid within the mass lesion is a characteristic finding. As a result of hemorrhagic fluid, hemosiderin pigment accumulation is observed in the periphery of the lesion (2)

Pyogenic granuloma, fibrous epulis, peripheral ossified fibroma, inflammatory fibrous hyperplasia, peripheral odontogenic fibroma, hemangioma cavenosum, and papilloma must be taken into consideration in differential diagnosis (10). The definitive diagnosis is based on histological examination ${ }^{(14)}$.

Histologically, these lesions resemble to central giant cell granulomas showing intraosseous localization (10). Because of this similarity, some pathologists consider PGCGs as the soft tissue counterpart of central giant cell granuloma. The differentiation is based on radiological evaluation ${ }^{(10)}$.

The treatment of these lesions involves excision and elimination of the local irritation ${ }^{(4)}$. Although recurrence is not frequent, it was reported that approximately $10 \%$ of these lesions could recur ${ }^{(4)}$. Aggressive behavior or malignant transformation has not been reported for these lesions ${ }^{(8)}$. 


\section{CONCLUSION}

Continuous irritation by local factors is an important element in the growth of these lesions to large sizes. Early recognition of the lesions and the elimination of local factors such as tartar and deep pockets are important steps in the treatment. The patients must be placed on a follow-up program even if these lesions have been reported to have a low recurrence rate.

\section{REFERENCES}

1. Tandon PN, Gupta SK, Gupta DS, Jurel SK, Saraswat A. Peripheral giant cell granuloma. Contemp Clin Dent 2012;3(Suppl 1):S11821.

2. Neville BW, Damm DD, Allen CM, Bouquot JE. Oral and maxillofacial pathology, 2th edition, p.449-50, W.B. Saunders Co., Philadelphia (2002).

3. Kfir Y, Buchner A, Hansen LS. Reactive lesions of the gingiva. A clinicopathological study of 741 cases. I Periodontol 1980;51(11):655-61.

4. Flaitz CM. Peripheral giant cell granuloma: a potentially aggressive lesion in children. Pediatr Dent 2000;22(3):232-3.

5. Mannem S, Chava VK. Management of an unusual peripheral giant cell granuloma: A diagnostic dilemma. Contemp Clin Dent 2012;3(1):93-6.

6. Bodner L, Peist M, Gatot A, Fliss DM. Growth potential of peripheral giant cell granuloma. Oral Surg Oral Med Oral Pathol Oral Radiol Endod 1997;83(5):548-51.

7. Barış E, Gültekin SE, Bozkaya S. A clinicopathologic evaluation of peripheral giant cell granulomas. J Dent Fac Atatürk Uni 2010;20(2):79-83.

8. Katsikeris N, Kakarantza-Angelopoulou E, Angelopoulos AP. Peripheral giant cell granuloma. Clinicopathologic study of 224 new cases and review of 956 reported cases. Int J Oral Maxillofac Surg 1988;17(2):94-9.

9. Lester SR, Cordell KG, Rosebush MS, Palaiologou AA, Maney P. Peripheral giant cell granulomas: a series of 279 cases. Oral Surg Oral Med Oral Pathol Oral Radiol 2014;118(4):475-82.

10. Regezi JA, Sciubba JJ, Jordan RCK. Oral pathology, clinical pathologic correlations, 4 th ed, p.116-7, W.B. Saunders Co.,. Philadelphia (2003)

11. Kibar S, Yılmaz H, Erdoğan BA, Şanlı A, Kayahan S. Sert Damakta Periferik Dev Hücreli Granülom. İstanbul Med J 2013;14:136-9.

12. Smith BR, Fowler CB, Svane TJ. Primary hyperparathyroidism presenting as a "peripheral" giantcell granuloma. J Oral Maxillofac Surg. 1988;46(1):65-9.

13. Burkes EJ, White RP. A peripheral giant-cell granuloma manifestation of primary hyperparathyroidism: report of case. J Am Dent Assoc 1989;118(1):62-4.14.

14. Cayci E, Kan B, Guzeldemir-Akcakanat E, Muezzinoglu B. Peripheral giant cell reparative granuloma of maxilla in a patient with aggressive periodontitis. Oral Health Dent Manag 2014;13(3):638-41. 